\title{
AIRCRAFT CLASSIFICATION FOR EFFICIENT \\ MODELLING OF ENVIRONMENTAL NOISE IMPACT OF \\ AVIATION
}

Antonio J. Torija* and Rod H. Self

ISVR, University of Southampton, Highfield Campus, SO17 1BJ Southampton, UK

Author to whom correspondence should be addressed. Electronic mail:

A.J.Martinez@soton.ac.uk

Tel.: +44 (0)2380592276 


\begin{abstract}
With the environmental externalities of civil aviation under unprecedented scrutiny, and with the projected significant increase in air traffic demand over the next few decades, fleet-level studies are required to assess the potential benefit of novel aircraft technologies and operational procedures for minimising environmental impact of aviation. Using a statistical classification process, the UK commercial aircraft fleet is reduced to four representative-in-class aircraft on the basis of aircraft physical characteristics, and aircraft noise and engine exhaust emissions. These four representative aircraft, that appropriately capture the noise and emissions characteristics for each category within the UK commercial fleet, are also selected to be used as baseline cases for the high-level assessment of the environmental benefit of novel aircraft technologies. For the particular case of aviation noise, the modelling tools are highly sensitive to the number of aircraft types in the flight schedule. A reduction of about $80 \%$ in computational time with relatively minor decrease in accuracy (between $-4 \%$ and $+5 \%$ ) is observed when the whole aircraft fleet is replaced with the four representative-in-class aircraft for computing noise contours. Therefore, the statistical classification and selection of representative-in-class aircraft presented in this paper is a valid approach for the rapid and accurate computation of a large number of exploratory cases to assess aviation noise reduction strategies.
\end{abstract}

Keywords: Aircraft noise; Engine exhaust emissions; Aviation environmental impacts; Fleetlevel studies; Noise contours; Noise modelling. 


\section{Introduction}

Aircraft noise is often the primary environmental factor of concern to communities living near airports (Durmaz, 2011). Clearly noticeable effects of aircraft noise include annoyance and sleep disturbance which significantly impacts on quality of life and welfare (Miedema, 2007). Less noticeably, Wolfe et al. (2017) found that aircraft noise from Heathrow and Gatwick airports in 2010 was associated with 57 myocardial infarctions leading to an estimated 17 premature mortalities, and estimated the total cost of noise in 2010 at $£ 81.2$ million a year. In addition to noise, aircraft engine exhaust emissions have direct and indirect effects upon climate (Ramanathan and Feng, 2009; Miyoshi and Merkert, 2015), and are detrimental to air quality in the locality of airports which is considered by some researchers to pose a real public health hazard (Barrett et al., 2013; Masiol and Harrison, 2014). Ashok et al. (2013) estimated that aviation LTO (i.e. Landing/Take-of cycle) emissions at US airports in 2005 caused about 195 early deaths, while LTO emissions were forecast to cause $\sim 350$ deaths in the US in 2018. Yim et al. (2013) also estimated that, based on data in 2005, airport emissions cause about 110 early deaths in the UK each year.

If the projected increase in air traffic demand over the next few decades (DfT, 2013; Airbus, 2016; Boeing, 2016) materialises then, without appropriate mitigation the environmental externalities of aviation might reach critical values, leading to a further deterioration of the relationships between aviation industry and communities around airports (Torija et al., 2017) and jeopardising the sustainability of air transport (Miyoshi and Merkert, 2015). To address such an issue, several technology programmes and environmental initiatives (ASTS, 2010; EC, 2011; Clean Sky Joint Undertaking, 2012; FAA, 2012; FAA, 2014; Del Rosario, 2014) have been established to explore different technology platforms, and thus develop technologies for minimising aircraft noise and emissions. Although these technologies might be evaluated at a vehicle-level, their environmental impact will be measured at a fleet- 
level considering the entire aircraft fleet composition and number of movements, flight procedures, and replacement strategies (Tetzloff and Crossley, 2014; Bernardo et al., 2015). These fleet-level studies involve a substantial number of variables with multiple combinations, therefore making the environmental impact assessment of different aviation scenarios a highly combinatorial and computationally expensive problem.

For the specific case of noise impact at ground-level due to airport operations, since thousands of potential scenarios might have to be evaluated before an 'optimal' solution is found, tools and/or methodologies are required that can rapidly analyse the noise impact of technology options, noise-abatement procedures and/or air traffic strategies (Dikshit and Crossley, 2009; Bernardo et al., 2016). Current high-fidelity airport noise models (Ollerhead et al., 1999; EMPA, 2010; FAA, 2008) allow the calculation of noise outputs with minimal uncertainty. For instance, Schäffer et al. (2014) estimated the uncertainty of the A-weighted equivalent continuous sound level $-\mathrm{L}_{\mathrm{Aeq}}-$ (see Section 2.2 for further details on $\mathrm{L}_{\mathrm{Aeq}}$ ) ranging from $0.5 \mathrm{~dB}$ (day) to $1.0 \mathrm{~dB}$ (night), when calculated with the airport noise model FLULA2 in Zurich and Geneva airports for past-time scenarios using radar data as input. However, these high-fidelity airport noise models achieve minimal uncertainty at the expense of a significant computational time, and therefore they are not always practical in preliminary strategic planning and decision making involving several technology options, noise-abatement procedures and/or air traffic strategies. To overcome such requirements of computational time and allow a rapid calculation of airport noise outputs, a number of simplified airport noise models for fleet-level studies have been developed (Dikshit and Crossley, 2009; Bernardo et al., 2015; Li et al., 2015; Torija et al., 2017). These simplified airport noise models assume several simplifications, which decrease the accuracy when computing noise outputs and restrict their application to some specific conditions and/or scenarios. For instance, as discussed in Torija et al. (2018), the simplified model developed by Dikshit and Crossley (2009) uses sound- 
levels measured at certification points for individual aircraft as input, which causes an important overestimation of noise contour areas (as compared to INM); the simplified model developed by Bernardo et al. (2015) assumes straight ground tracks, which can lead to important errors when computing noise contours at busy airports; the simplified model developed by Torija et al. (2017) assumes straight ground tracks, and it is restricted to single runway airports.

The computational time of airport noise models is most sensitive to the number of aircraft in the flight schedule (Bernardo et al., 2015). Therefore, another approach for reducing the combinatorial nature of the problem is the classification of the fleet into representative aircraft categories, and then selecting an indicative aircraft representative of each category (Hollingsworth and Sulitzer, 2011; Tetzloff and Crossley, 2014). With this approach, noise outputs can be more rapidly computed with either high-fidelity or simplified airport noise models using only a reduced number of aircraft types, i.e. a representative aircraft for each category.

LeVine et al. (2017) proposed a novel method to define average generic vehicles for fleet-level modelling of aviation noise and emissions. Firstly, the fleet of (in-production) aircraft with a significant number of operations at a subset of 94 US airports was grouped, using a linear discriminant analysis, into a number of classes on the basis of three aircraft-level metrics: fuel burn, $\mathrm{NO}_{\mathrm{x}}$ emissions, and Sound Exposure Level (SEL) noise contours (see Section 2.2 for further details on SEL). Then, the so-called GENERICA method implemented designs of experiments, surrogate models, Monte Carlo simulations, and multicriteria decisionmaking techniques to define class-based average generic vehicles for more realistic approximation of fleet-level results. When aggregated noise contours were computed for the subset of 94 US airports under study, the average generic vehicles were found less robust than the representative-in-class vehicles. The authors suggested that the higher average error and 
standard deviations when computing noise contours with the average generic vehicles was mainly due to the presence (in the 94 US airports subset) of airports (typically with low volume of operations) where the operations were significantly dominated by one single aircraft type. Conversely, for airports with more operations distributed across several aircraft types, the average generic vehicles were found to be very accurate.

A significant number of UK airports have a reduced volume of operations, and even in London Gatwick airport (second busiest airport in the UK) almost 65\% of the operations involve Airbus A319 and A320 aircraft types (see Lee et al. 2017b). Therefore, based on the characteristics of the aircraft fleet and airports in the UK, this research implemented a representative-in-class approach where a cluster analysis was applied for grouping the UK commercial aircraft fleet into a number of aircraft categories (with minimal within-group variance) on the basis of aircraft physical characteristics, and aircraft noise and engine exhaust emissions; and then selected a representative aircraft for each aircraft category identified. The ultimate goal is to reduce the fleet to a number of representative vehicles that capture the noise and engine exhaust emission characteristics for each aircraft category in a holistic way. Although these representative-in-class vehicles were selected to address efficient aviation noise and emissions fleet-level studies without compromising accuracy, this paper focuses specifically on the application to aviation noise. Using an hypothetical airport, with both the fleet in 2015 at London Heathrow and London Gatwick airports, aggregated noise contour areas were calculated with the whole fleet and solely with the representative-in-class aircraft in order to assess the validity of the proposed method. These representative-in-class aircraft were also selected with the objective to be used as baseline cases for the high-level examination of general technological improvements for reducing the aviation noise and emissions impact (at a fleet-level). 


\section{Methodology}

\subsection{Aircraft database}

The aircraft fleet with scheduled flights in 2015 in the UK was obtained from the Sabre AirVision Market Intelligence database ${ }^{1}$, and from the movements (per aircraft type) database used by the UK Civil Aviation Authority (CAA) for computing the noise exposure contours around London airports ${ }^{2}$. From these aircraft databases, the aircraft types with data published in the Aircraft Noise and Performance (ANP) database ${ }^{3}$ were selected for the analysis carried out in this research. This excluded the aircraft type Airbus A350-900 (with 64 cycles during year 2015 in the UK, according to Sabre AirVision Market Intelligence database) which is not yet included in the ANP database. This exclusion did not affect the noise calculations performed with the aircraft fleet at Heathrow and Gatwick airports (see Section 3.3), since there were no scheduled flights of the A350-900 aircraft in these airports in year 2015 (see Lee et al. 2017a,b). Moreover, this research only considered jet-propelled aircraft, which represented the $88 \%$ of the total aircraft movements in the UK in year 2015 (according to Sabre AirVision Market Intelligence database). Only jet engines (turbojets and turbofans) are included in the ICAO Aircraft Engine Emissions (AEE) databank ${ }^{4}$ (ICAO, 2008), the database used in this research for characterizing the engine exhaust emissions for each aircraft type. For the specific cases of Heathrow and Gatwick airports, large twin-turboprop aircraft represented (in year 2015 ) only the $0.02 \%$ and $1.23 \%$ of the total of aircraft movements (see Lee et al. $2017 \mathrm{a}, \mathrm{b}$ ). Table 1 shows the 38 aircraft types composing the final database used for this research, including the aircraft designation, the associated Integrated Noise Model (INM) type, the

\footnotetext{
${ }^{1}$ https://www.sabreairlinesolutions.com/home/software_solutions/product/market_competitive_intelligence/

$2 \mathrm{https} / / /$ www.gov.uk/government/publications/noise-exposure-contours-around-london-airports

${ }^{3} \mathrm{https}: / / \mathrm{www}$.aircraftnoisemodel.org/

${ }^{4}$ https://www.easa.europa.eu/document-library/icao-aircraft-engine-emissions-databank
} 
airframe manufacturer, and the engine type and manufacturer. The specific engine of each aircraft type as shown in Table 1 was assigned based on the aircraft records published in the ANP database.

\section{Table 1}

Aircraft fleet database.

\begin{tabular}{|c|c|c|c|}
\hline Aircraft designation & INM aircraft & Airframe & Engine \\
\hline $717-200$ & 717200 & Boeing & BR715 (BMW Rolls-Royce) \\
\hline $737-300$ & 737300 & Boeing & CFM56-3B-1 (CFM International) \\
\hline $737-400$ & 737400 & Boeing & CFM56-3C-1 (CFM International) \\
\hline $737-500$ & 737500 & Boeing & CFM56-3C-1 (CFM International) \\
\hline $737-700$ & 737700 & Boeing & CFM56-7B24 (CFM International) \\
\hline $737-800$ & 737800 & Boeing & CFM56-7B26 (CFM International) \\
\hline $747-400$ & 747400 & Boeing & PW4056 (Pratt \& Whitney) \\
\hline $747-8$ & 7478 & Boeing & GEnx-2B67 (General Electric) \\
\hline $757-300$ & 757300 & Boeing & RB211-535E4B (Rolls-Royce) \\
\hline $757-200$ & 757PW & Boeing & PW2037 (Pratt \& Whitney) \\
\hline $757-200$ & 757RR & Boeing & RB211-535E4 (Rolls-Royce) \\
\hline $767-200$ & $767 \mathrm{CF} 6$ & Boeing & CF6-80A (General Electric) \\
\hline $767-300$ & 767300 & Boeing & PW4060 (Pratt \& Whitney) \\
\hline 767-400ER & 767400 & Boeing & CF6-80C2B(F) (General Electric) \\
\hline 777-200ER & 777200 & Boeing & GE90-90B (General Electric) \\
\hline $777-300$ & 777300 & Boeing & TRENT-892 (Rolls-Royce) \\
\hline $787-8$ & $787 \mathrm{R}$ & Boeing & TRENT-1000-C/01 (Rolls-Royce) \\
\hline A300 & A300-622R & Airbus & PW4158 (Pratt \& Whitney) \\
\hline A310 & A310-304 & Airbus & CF6-80C2A2 (General Electric) \\
\hline A319 & A319-131 & Airbus & V2522-A5 (International Aero Engines) \\
\hline A320 & A320-211 & Airbus & CFM56-5A1 (CFM International) \\
\hline A320 & A320-232 & Airbus & V2527-A5 (International Aero Engines) \\
\hline A321 & A321-232 & Airbus & V2530-A5 (International Aero Engines) \\
\hline A330 & A330-301 & Airbus & CF6-80E1A2 (General Electric) \\
\hline A330 & A330-343 & Airbus & TRENT-772B (Rolls-Royce) \\
\hline A340-200 & A340-211 & Airbus & CFM56-5C2 (CFM International) \\
\hline A340-600 & A340-642 & Airbus & TRENT-556 (Rolls-Royce) \\
\hline A380 & A380-841 & Airbus & TRENT-970 (Rolls-Royce) \\
\hline A380 & A380-861 & Airbus & GP7270 (Engine Alliance) \\
\hline BAE146-200 & BAE146 & $\mathrm{BAE}$ & ALF502R-5 (Lycoming) \\
\hline CRJ-700 & CRJ701 & Bombardier & BR710 (BMW Rolls-Royce) \\
\hline CRJ-900 & CRJ900 & Bombardier & BR710 (BMW Rolls-Royce) \\
\hline Embraer 135 & EMB135 & Embraer & AE3007 (Allison) \\
\hline Embraer 145ER & EMB145 & Embraer & AE3007 (Allison) \\
\hline Embraer 170 & EMB170 & Embraer & BR710 (BMW Rolls-Royce) \\
\hline Embraer 190 & EMB190 & Embraer & BR710 (BMW Rolls-Royce) \\
\hline Fokker 100 & F10062 & Fokker & TAY 620-15 (BMW Rolls-Royce) \\
\hline Fokker 100 & F10065 & Fokker & TAY 650-15 (BMW Rolls-Royce) \\
\hline
\end{tabular}


As stated above, this research was aimed at selecting a number of representative-inclass aircraft that capture the environmental performance of the different aircraft categories within the UK commercial fleet, but also at selecting baseline cases for modelling the environmental benefit of aircraft technology improvements. During the design stage of the aircraft database for this research, it was decided to include any aircraft type with scheduled flights in the UK in year 2015 (with the exceptions explained above) regardless they are inproduction or out-of-production. Although the inclusion of out-of-production aircraft might affect the selection of the baseline cases for technology-infused aircraft studies, it was considered absolutely necessary for the environmental modelling of the current aircraft fleet in the UK.

\subsection{Variables for aircraft classification}

A number of variables were selected for performing the clustering analysis of the aircraft fleet database shown in Table 1. As shown in Table 2 a set of variables were considered for the physical characterization of the aircraft, and for measuring the aircraft noise and engine exhaust emissions (at a vehicle-level).

The environmental performance of a given aircraft is clearly linked to the parameters defining the physical characteristics of aircraft and engines. Six variables were selected for the physical characterization of the aircraft because of their assumed relevance for the aircraft noise and engine exhaust emissions. These physical variables were used for the clustering process as they are required in order to define baseline cases for studies examining technology improvements (LeVine et al., 2017). Also, these physical variables were used to help with the interpretation of the set of clusters obtained with the clustering process. The three variables for the physical characterization of aircraft engines used in the ICAO AEE databank were 
selected: Bypass Ratio (BPR), i.e. the ratio of the air mass flow through the bypass ducts of a gas turbine engine to the air mass flow through the engine core; Overall Pressure Ratio (OPR), i.e. the ratio of the mean total pressure at the last compressor discharge plane of the compressor to the mean total pressure at the compressor entry plane when the engine is developing takeoff thrust rating in $\mathrm{ISA}^{5}$ sea level static conditions; and Rated Output $\left(\mathrm{F}_{00}\right)$, i.e. the maximum thrust available for take-off under normal operating conditions at ISA sea level static conditions (ICAO, 2008). Moreover, there were also selected the physical variables Number of Engines (NoE), and the Departure and Landing Aircraft Weights (DW and LW respectively) defined for a series of "Standard" flight profiles, as found in both the ANP database and INM 7.0 software database. The aircraft weights were determined as the operating empty weights plus the total payload plus the fuel load (i.e. fuel required for representative trip length plus reserves) (FAA, 2008).

In this paper, the aircraft noise emission at a vehicle-level is measured using SEL noise contours. The SEL of an aircraft noise event is the sound level, in dBA, of a one second burst of steady noise that contains the same total sound energy as the whole event (Jones and Cadoux, 2009). The SEL is usually use for comparing the noise emission of individual aircraft. The noise exposure at a fleet-level is measured, in this paper, using the A-weighted equivalent continuous sound level $\left(\mathrm{L}_{\text {Aeq, }}\right)$. The $\mathrm{L}_{\text {Aeq,t }}$ aggregates all the individual aircraft noise events over a specific time period. The $\mathrm{L}_{\mathrm{Aeq}, 16 \mathrm{~h}}$ (covering the period 7-23 h) is the metric used in the UK for computing noise contour areas, and so it was used in this paper for the calculation of noise contour areas presented in Section 3.3.

Assuming a straight-in/straight-out trajectory, the 100-, 90- and 80-SEL contour area was calculated for each aircraft type using INM. These three SEL contours were selected as

\footnotetext{
${ }^{5}$ International Standard Atmosphere
} 
representative of the maximum sound-levels when the aircraft is flying at maximum take-off power, of the sound-levels further away from the airport when the aircraft is flying with a reduced power, and of the threshold for community noise annoyance respectively. These noise contour areas were calculated for two conditions: landing and departure. At the departure condition, for each aircraft type, the noise contour areas were calculated for the whole set of "Standard" flight procedures published in the ANP database. The final departure noise contour areas assigned to each aircraft type were the average values of the noise contour areas computed using the set of departure "Standard" flight procedures. This process was also used for obtaining an average departure weight for each aircraft.

\section{Table 2}

Independent variables for clustering.

\begin{tabular}{|c|c|}
\hline & Variables \\
\hline Physical characteristics & $\begin{array}{l}\text { Number of Engines }(\mathrm{NoE}) \\
\text { Bypass Ratio (BPR) } \\
\text { Overall pressure ratio (OPR) } \\
\text { Rated output }\left(\mathrm{F}_{00}\right) \\
\text { Average Departure Weight (DW) } \\
\text { Landing Weight }(\mathrm{LW})\end{array}$ \\
\hline Aircraft noise emission & $\begin{array}{l}\text { 80-SEL noise contour area (Departure) } \\
\text { 90-SEL noise contour area (Departure) } \\
\text { 100-SEL noise contour area (Departure) } \\
\text { 80-SEL noise contour area (Landing) } \\
\text { 90-SEL noise contour area (Landing) } \\
\text { 100-SEL noise contour area (Landing) }\end{array}$ \\
\hline Aircraft engine exhaust emission & $\begin{array}{l}\text { LTO total fuel } \\
\text { LTO total HC } \\
\text { LTO total } \mathrm{CO} \\
\text { LTO total } \mathrm{NO}_{\mathrm{x}} \\
\mathrm{HC} / \mathrm{F}_{00} \\
\mathrm{CO} / \mathrm{F}_{00} \\
\mathrm{NO}_{\mathrm{x}} / \mathrm{F}_{00}\end{array}$ \\
\hline
\end{tabular}


This research only considered the aircraft engine exhaust emissions during the LTO cycle, therefore below $915 \mathrm{~m}(3,000 \mathrm{ft})$. The engine exhaust emissions considered in this research were the total $\mathrm{HC}, \mathrm{CO}$ and $\mathrm{NO}_{\mathrm{x}}$ emitted during the LTO cycle. The clustering process addressed in this research did not use mission level metrics, so that, in order to avoid that clusters were overfit to the local area emission metrics, three relative measures were considered, i.e. the mass of $\mathrm{HC}, \mathrm{CO}$ and $\mathrm{NO}_{\mathrm{x}}$ emitted during the LTO cycle divided by the rated output of the engine. Moreover, the total fuel burnt during the LTO cycle was used for the clustering process. The fuel burnt is a direct proxy for $\mathrm{CO}_{2}$ emissions, at a ratio of $\sim 3.155$ kilograms of $\mathrm{CO}_{2}$ produced per kilogram of fuel (Bernardo, et al., 2012). This data was obtained from the AEE databank.

\subsection{Statistical classification process}

The set of physical variables (described above) were used in the clustering process under the assumption of their relevance for explaining aircraft noise and engine exhaust emissions. A series of multiple linear regression (MLR) analyses were performed in order to validate the correlation between the six variables used for the physical characterization of aircraft and the variables used for measuring aircraft noise and engine exhaust emissions.

A hierarchical cluster analysis (HCA) based on the independent variables described above was conducted in order to group the aircraft fleet into a number of representative categories. This HCA was performed using Ward's method for clustering and with the squared Euclidean distance as the interval measure. Based on an agglomerative process, the Ward's method iteratively allows for the merging of the two clusters that will increase the total withincluster variance by the minimum possible (Torija et al., 2013; de Amorim, 2015). The "elbow criterion" was used for selecting the appropriate number of clusters in the aircraft dataset 
(Torija and Ruiz, 2016). This criterion assumes that the "optimal" number of clusters is found when there is a significant increase in the inter-cluster distance. For each aircraft category determined an aircraft was selected as representative, on the basis of the smallest distance to the centroid of the category.

After the HCA, a linear discriminant analysis was carried out to identify which of the physical and environmental (noise and engine exhaust emissions) variables are most influential for the differentiation between the different aircraft categories observed. Moreover, a series of Independent-samples Kruskal Wallis tests were carried out for testing whether there are statistically significant differences between the aircraft categories observed, from the environmental standpoint. These Kruskal Wallis tests allowed also a 'sanity check' of the aircraft categories found with the HCA, using a totally different approach for the differential comparison between categories.

\section{Results}

\subsection{Aircraft classification based on physical and environmental characteristics}

A series of MLR were performed in order to validate the correlation between all the variables used for the physical characterization of the aircraft and the environmental variables

(Table 2). Based on the results of these MLR analyses (t-tests), a clear correlation was found between all the six physical variables selected and the aircraft noise and emissions variables (see Table 3). 


\section{Table 3}

Most influential physical variables (selected for aircraft characterisation) for each environmental variables (noise and engine emissions). All showed physical variables with $p$-value $\leq 0.05$.

\begin{tabular}{|l|l|}
\hline Environmental variables & Most influential physical variables \\
\hline 80-SEL noise contour area (Departure) & BPR \\
\hline 90-SEL noise contour area (Departure) & BPR, NoE \\
\hline 100-SEL noise contour area (Departure) & BPR, $\mathrm{F}_{00}, \mathrm{NoE}$ \\
\hline 80-SEL noise contour area (Landing) & None \\
\hline 90-SEL noise contour area (Landing) & None \\
\hline 100-SEL noise contour area (Landing) & None \\
\hline LTO total fuel & BPR, $\mathrm{F}_{00}, \mathrm{NoE}, \mathrm{DW}, \mathrm{OPR}$ \\
\hline LTO total HC & OPR \\
\hline LTO total CO & OPR \\
\hline LTO total NO & $\mathrm{F}_{00}, \mathrm{DW}, \mathrm{LW}, \mathrm{NoE}$ \\
\hline $\mathrm{HC} / \mathrm{F}_{00}$ & $\mathrm{OPR}, \mathrm{F}_{00}$ \\
\hline $\mathrm{CO} / \mathrm{F}_{00}$ & $\mathrm{OPR}$ \\
\hline $\mathrm{NO} \mathrm{x}_{\mathrm{x}} \mathrm{F}_{00}$ & $\mathrm{~F}_{00}, \mathrm{BPR}, \mathrm{LW}, \mathrm{DW}$ \\
\hline
\end{tabular}

Prior to the HCA, the "optimal" number of clusters was investigated by analyzing the inter-cluster distances during the clustering process ("elbow criterion"). As shown in Fig. 1, when the aircraft fleet under study is reduced to 4 clusters there is a notable increase in the inter-cluster distance. Based on these results 4 aircraft categories were assumed to represent the whole aircraft fleet on the basis of the physical and environmental variables used for the analysis. 


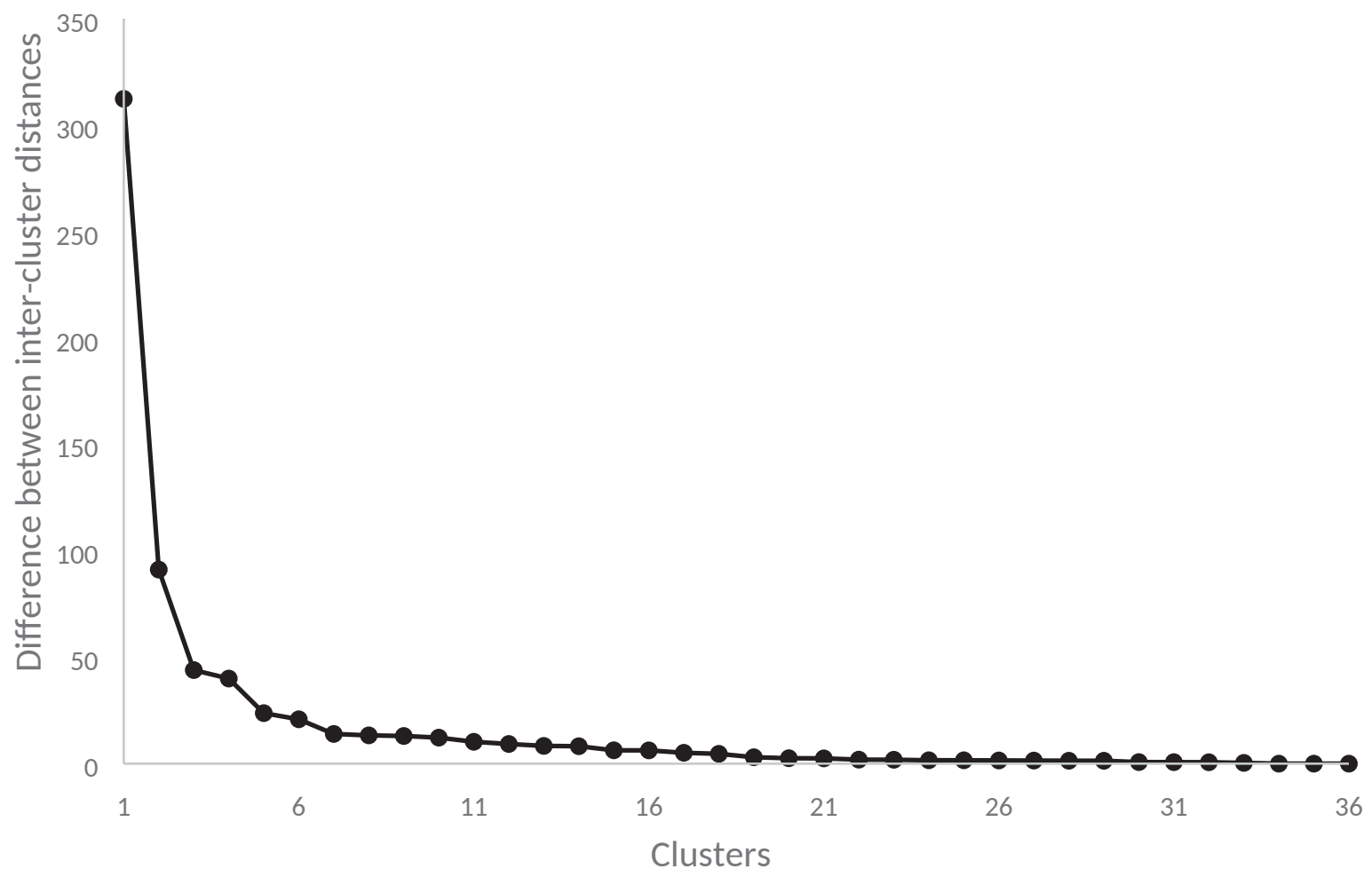

Fig. 1. Difference between inter-cluster distances in HCA.

The dendrogram using Ward linkage with squared Euclidean distance as the measure unit (Fig. 2) also confirms this result, identifying 4 main aircraft categories: (1) Regional aircraft with 2 engines, and 32.5/28.9 t as DW and LW; (2) Short-Medium haul with 2 engines, and 71.4/62.9 $\mathrm{t}$ as DW and LW; (3) Long haul with 4 engines, and 384.5/304.8 $\mathrm{t}$ as DW and LW; and (4) Long haul with 2 engines, and 176.0/152.6 $t$ as DW and LW. The average value of the engine physical variables for each of these 4 aircraft categories are: (1) BPR $=4.32$, OPR $=19.77$ and $\mathrm{F}_{00}=54.41 \mathrm{kN}$; (2) $\mathrm{BPR}=4.95, \mathrm{OPR}=26.74$ and $\mathrm{F}_{00}=123.25 \mathrm{kN}$; (3) $\mathrm{BPR}=$ 7.28, $\mathrm{OPR}=37.02$ and $\mathrm{F}_{00}=296.64 \mathrm{kN} ;$ and $(4) \mathrm{BPR}=5.89, \mathrm{OPR}=33.70$ and $\mathrm{F}_{00}=284.70$ $\mathrm{kN}$. 


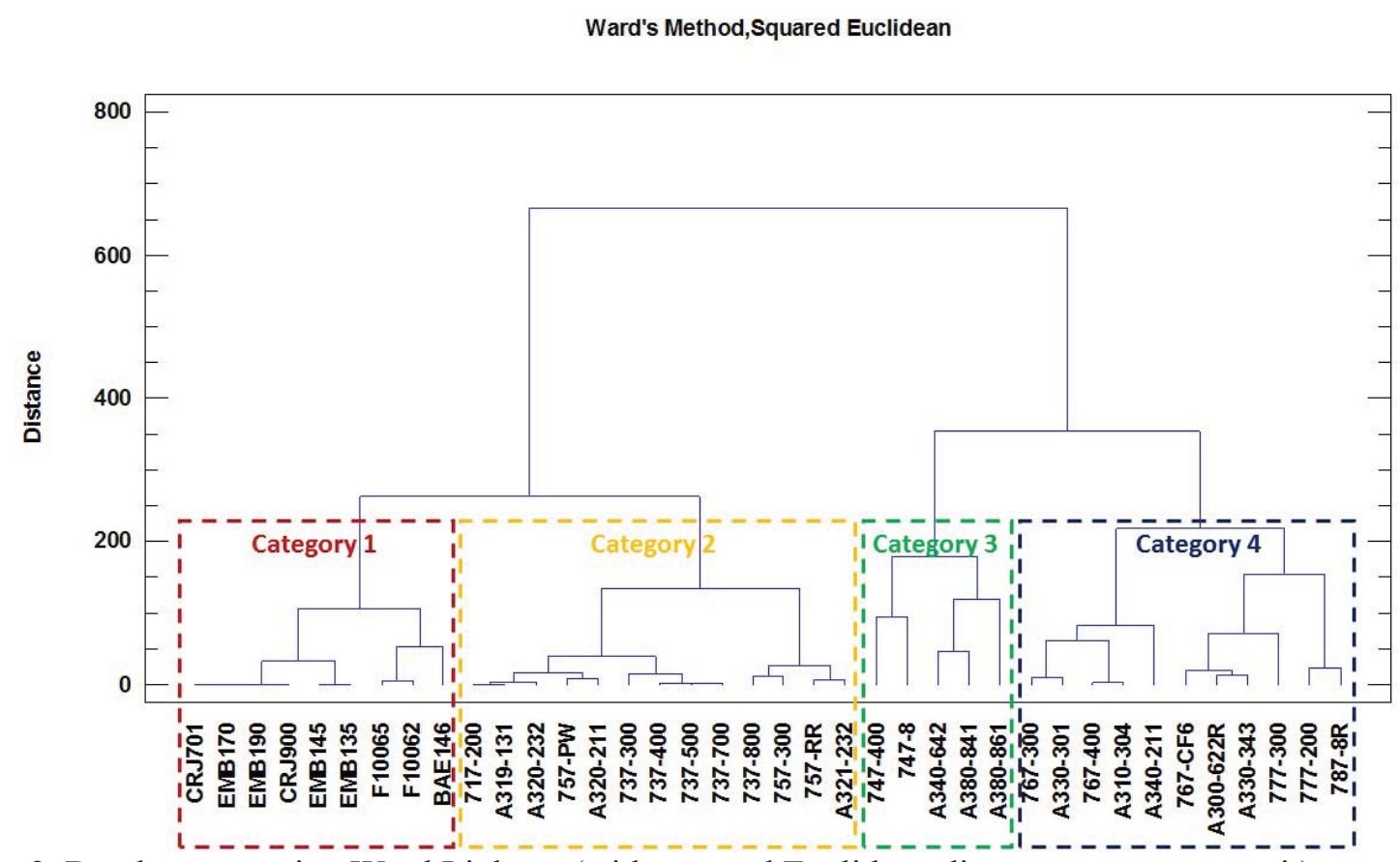

Fig. 2. Dendrogram using Ward Linkage (with squared Euclidean distance as measure unit).

The aircraft types with the smallest distance to the centroid of the corresponding category were selected as representative-in-class (Table 4). There was one exception for the specific case of category 2. For this category, the aircraft type with the smallest distance to centroid was the Boeing 737-700, but the representative-in-class aircraft selected was the Airbus 321-232. Both aircraft have a similar distance to centroid: 737-700 $=0.004$ and A321$232=0.018$ (in a range 0.004-0.080). The aircraft A321-232 was selected as representativein-class because of its flights scheduled in the UK in year $2015(82,321)$, as compared to the flights scheduled for 737-700 (only 6,045). Also, with the selection of the aircraft A321-232, the four representative-in-class aircraft selected are consistent with the selection of reference aircraft for noise technology studies conducted by the ICAO Committee on Aviation Environmental Protection (CAEP) (Adib, 2014 - Figs. C.1 to C.4). 


\section{Table 4}

Representative-in-class aircraft for each category.

\begin{tabular}{|l|l|l|}
\hline Aircraft category & Aircraft type & Entry into service (year) \\
\hline 1 & CRJ-900 & 2001 \\
\hline 2 & A321-232 & 1993 \\
\hline 3 & $747-8$ & 2012 \\
\hline 4 & A330-343 & 1992 \\
\hline
\end{tabular}

The most influential (physical and environmental) variables for the differentiation between the aircraft categories identified in the HCA were determined using a linear discriminant analysis. For the discrimination of the 4 aircraft categories identified on the basis of the value of the set of the physical and environmental variables used, 3 discriminant functions were built explaining the $85.9 \%, 11.4 \%$ and $2.8 \%$ of the variance. As observed in Table 5, the variables with the highest correlations with the discriminant function 1 are: LTO total fuel, LW, DW, LTO total NOx and the 90-SEL noise contour area during landing conditions. Therefore, these are the most influential variables for the discrimination between the four aircraft categories found. $\mathrm{F}_{00}, \mathrm{OPR}, \mathrm{BPR}, \mathrm{NO}_{\mathrm{x}} / \mathrm{F}_{00}$, and the other noise emission variables seem to have a reduced influence for the discrimination, while the other engine exhaust emission variables have very little contribution for the discrimination.

\section{Table 5}

Pooled within-groups correlations between discriminating variables and standardised canonical discriminant functions. * Largest absolute correlation between each variable and any discriminant function.

\begin{tabular}{|l|l|l|l|}
\hline \multirow{2}{*}{ Variables } & \multicolumn{3}{|c|}{ Discriminant functions } \\
\cline { 2 - 4 } & 1 & 2 & 3 \\
\hline LTO total fuel & $0.335^{*}$ & 0.248 & 0.088 \\
\hline LW & $0.295^{*}$ & 0.220 & 0.105 \\
\hline DW & $0.289^{*}$ & 0.176 & 0.071 \\
\hline LTO total $\mathrm{NO}_{\mathrm{x}}$ & $0.209^{*}$ & 0.195 & 0.119 \\
\hline 90-SEL noise contour area (Landing) & $0.163^{*}$ & 0.158 & -0.063 \\
\hline NoE & $0.131^{*}$ & -0.104 & -0.015 \\
\hline
\end{tabular}




\begin{tabular}{|l|l|l|l|}
\hline $\mathrm{F}_{00}$ & 0.132 & $0.343^{*}$ & 0.237 \\
\hline OPR & 0.100 & $0.243^{*}$ & 0.002 \\
\hline $100-S E L$ noise contour area (Departure) & 0.119 & $0.236^{*}$ & -0.070 \\
\hline $100-S E L$ noise contour area (Landing) & 0.128 & $0.209^{*}$ & -0.076 \\
\hline $\mathrm{NO}_{\mathrm{x} / \mathrm{F}_{00}}$ & 0.030 & $0.161^{*}$ & -0.014 \\
\hline 90-SEL noise contour area (Departure) & 0.109 & $0.157^{*}$ & -0.008 \\
\hline $80-\mathrm{SEL}$ noise contour area (Departure) & 0.117 & $0.143^{*}$ & -0.022 \\
\hline $80-\mathrm{SEL}$ noise contour area (Landing) & 0.132 & $0.134^{*}$ & 0.007 \\
\hline $\mathrm{BPR}$ & 0.074 & $0.083^{*}$ & 0.005 \\
\hline $\mathrm{HC} / \mathrm{F}_{00}$ & -0.024 & -0.001 & $0.371^{*}$ \\
\hline $\mathrm{LTO}$ total HC & 0.022 & 0.130 & $0.272^{*}$ \\
\hline $\mathrm{CO} / \mathrm{F}_{00}$ & -0.054 & -0.132 & $0.230^{*}$ \\
\hline $\mathrm{LTO}$ total CO & 0.077 & 0.113 & $0.181^{*}$ \\
\hline
\end{tabular}

\subsection{Environmental impact aviation metric}

For the purpose of assessing the environmental impact of individual aircraft, this research defines the Environmental Impact Aviation metric (EIAm). The calculation of EIAm is based on the environmental variables: $80-, 90-$ and 100-SEL contour areas at departure and landing conditions, the total fuel burnt during the LTO cycle, and the total $\mathrm{HC}, \mathrm{CO}$ and $\mathrm{NO}_{\mathrm{x}}$ emitted during the LTO cycle. The range (minimum value - maximum value) of each environmental variable was re-scaled (normalised) to a 0-1 range. For the calculation of EIAm each (normalised) environmental variable $\left(E_{i}\right)$ is multiplied by a weighting factor $\left(w_{i}\right)$ accounting for the negative effects on both the surrounding environment and the communities affected:

$$
\text { EIAm }=\sum_{i=1}^{10}\left(w_{i} E_{i}\right)
$$




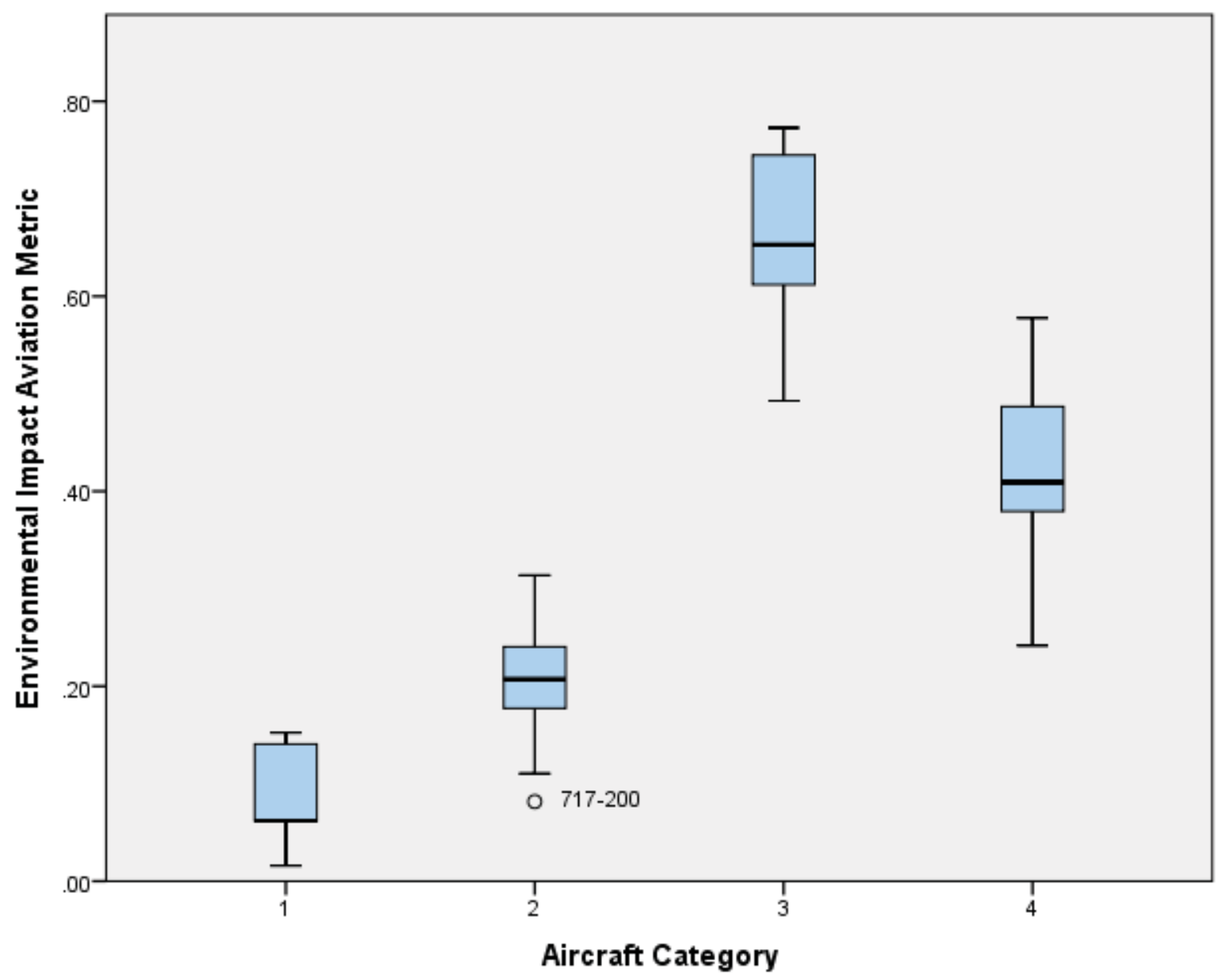

Fig. 3. Box-plot diagram with the value of the environmental impact aviation metric, EIAm (all $w_{i}=1$ ), for each aircraft category.

If all weighting factors $\left(w_{i}\right)$ are set equal to 1 (Fig. 3), the average value of EIAm is $0.08,0.20,0.66$ and 0.43 for the aircraft categories $1,2,3$ and 4 respectively. As observed in Fig. 3, the environmental impact of individual aircraft increases significantly from regional aircraft (category 1) to long haul aircraft with 4 engines (category 3 ). This trend is especially apparent in the variables LTO Total Fuel, LTO Total $\mathrm{NO}_{\mathrm{x}}$ and 90-SEL contour area (landing). Despite similar range characteristics, the environmental impact of quad long haul aircraft during a LTO cycle is equivalent to 1.5 LTO cycles of a twin long haul aircraft (category 4).

A series of Independent-samples Kruskal Wallis tests were performed for the pairwise comparison of the EIAm (all $w_{i}=1$ ) of each aircraft category identified (Table 6). These tests, 
as a different approach for differential comparison, were used to 'sanity check' the aircraft categories identified with the HCA (from the environmental standpoint). Statistically significant differences $(\mathrm{p} \leq 0.05)$ are observed between aircraft category 1 and aircraft categories 3 and 4, and between aircraft category 2 and aircraft categories 3 and 4 . Therefore, only the environmental impact of regional and short/medium haul aircraft (categories 1 and 2), and long haul aircraft (categories 3 and 4) is statistically different. Although the results of the Kruskal Wallis tests suggested that, from an environmental perspective, there might only be two categories (categories $1 / 2$ and 3/4), with a conservative approach it was decided to consider the 4 aircraft categories identified with HCA. Moreover, four aircraft categories allow much more refined aircraft technology-infused studies.

\section{Table 6}

Pairwise comparisons of the environmental impact aviation metric (EIAm) of each aircraft category (Independent-samples Kruskal Wallis test). *Statistically significant differences (p-value $\leq 0.05$ ).

\begin{tabular}{|l|l|l|l|l|}
\hline & $\begin{array}{l}\text { Aircraft } \\
\text { category 1 }\end{array}$ & $\begin{array}{l}\text { Aircraft } \\
\text { category 2 }\end{array}$ & $\begin{array}{l}\text { Aircraft } \\
\text { category 3 }\end{array}$ & $\begin{array}{l}\text { Aircraft } \\
\text { category 4 }\end{array}$ \\
\hline $\begin{array}{l}\text { Aircraft } \\
\text { category 1 }\end{array}$ & - & 0.261 & $0.000^{*}$ & $0.000^{*}$ \\
\hline $\begin{array}{l}\text { Aircraft } \\
\text { category 2 }\end{array}$ & 0.261 & - & $0.004^{*}$ & $0.039^{*}$ \\
\hline $\begin{array}{l}\text { Aircraft } \\
\text { category 3 }\end{array}$ & $0.000^{*}$ & $0.004^{*}$ & - & 1.000 \\
\hline $\begin{array}{l}\text { Aircraft } \\
\text { category 4 }\end{array}$ & $0.000^{*}$ & $0.039^{*}$ & 1.000 & - \\
\hline
\end{tabular}

\subsubsection{EIAm for global and local impact}

On the basis of the weighting factors $\left(w_{i}\right)$ chosen, the EIAm can be used for assessing the aircraft environmental impact at both a local or on a global scale. The so-called impact weight for each environmental impact considered in this research, i.e. climate, air quality and 
noise, was computed from the environmental damage of aviation calculated by Wolfe et al. (2014). The climate, air quality and noise damage (in 2006 USD) calculated by Wolfe et al. (2014 - Fig. 1) at a global and local (within $5 \mathrm{~km}$ of the airport) scale were re-scaled to a $0-1$ range for computing the impact weights: climate $=0.22$, air quality $=0.22$ and noise $=0.56$ for a local scale, and climate $=0.72$, air quality $=0.19$ and noise $=0.09$ for a global scale. The socalled within-impact weights for the air quality emissions considered were computed on the basis of their impact on human health as reviewed by Mahashabde et al. (2011) and Masiol and Harrison (2014). A clearer link to adverse health effects on exposed people is suggested for $\mathrm{HC}$ and $\mathrm{NO}_{\mathrm{x}}$ emissions than for $\mathrm{CO}$ emissions (Mahashabde et al., 2011; Masiol and Harrison, 2014). For this reason, using a $0-1$ scale, both $\mathrm{HC}$ and $\mathrm{NO}_{\mathrm{x}}$ were given a within-impact weight of 0.4 , while $\mathrm{CO}$ was given a within-impact weight of 0.2 . The within-impact weight for the noise variables considered were computed using the exposure-response function derived by Fidell and Silvati (2004) for quantifying the percentage of people annoyed by a given aircraft noise level. Exposure-response functions allow an appropriate prediction of community-wide response (Mahashabde et al., 2011). The 80-, 90- and 100-SEL values were converted to DNL values (using the overall number of day and night movements at Heathrow airport in year 2015 (Lee et al., 2017a)), then the corresponding percentages of annoyed people were calculated using the Fidell and Silvati (2004) exposure-response function, and finally, these percentages of annoyed people were re-scaled to a 0-1 range for computing the within-impact weights: 80$\mathrm{SEL}=0.170,90-\mathrm{SEL}=0.319$ and $100-\mathrm{SEL}=0.512$. It should be noted that, because two different noise contour areas were calculated for each SEL value (e.g. 80-SEL noise contour area for departure and landing operations), the final within-impact weights for noise were computed as, for instance, 80-SEL noise contour area (departure/landing) $=0.170 / 2=0.085$. 
The resulting weighting factor $\left(w_{i}\right)^{6}$ for each environmental variable $\left(E_{i}\right)$, for assessing local and global impacts, is shown in Table 7.

\section{Table 7}

Weighting factors $\left(w_{i}\right)$ for the calculation of EIAm for global and local impacts.

\begin{tabular}{|c|c|c|c|c|c|c|c|}
\hline \multirow[t]{2}{*}{ Impact } & \multirow{2}{*}{$\begin{array}{l}\text { Environmental } \\
\text { variable }\left(E_{i}\right)\end{array}$} & \multicolumn{3}{|l|}{ Local } & \multicolumn{3}{|l|}{ Global } \\
\hline & & $\begin{array}{l}\text { Impact } \\
\text { weight }\end{array}$ & $\begin{array}{l}\text { Within- } \\
\text { impact } \\
\text { weight }\end{array}$ & $\begin{array}{l}\text { Weighting } \\
\text { factor }\left(w_{i}\right)\end{array}$ & $\begin{array}{l}\text { Impact } \\
\text { weight }\end{array}$ & $\begin{array}{l}\text { Within- } \\
\text { impact } \\
\text { weight }\end{array}$ & $\begin{array}{l}\text { Weighting } \\
\text { factor }\left(w_{i}\right)\end{array}$ \\
\hline \multirow[t]{4}{*}{ Noise } & $\begin{array}{l}\text { 80-SEL noise } \\
\text { contour area } \\
\text { (Departure) }\end{array}$ & 0.560 & 0.085 & 0.047 & \multirow[t]{4}{*}{0.090} & 0.085 & 0.008 \\
\hline & $\begin{array}{l}\text { 90-SEL noise } \\
\text { contour area } \\
\text { (Departure) }\end{array}$ & & 0.159 & 0.089 & & 0.159 & 0.014 \\
\hline & $\begin{array}{l}\text { 100-SEL noise } \\
\text { contour area } \\
\text { (Departure) }\end{array}$ & & 0.256 & 0.143 & & 0.256 & 0.023 \\
\hline & $\begin{array}{l}\text { 80-SEL noise } \\
\text { contour area } \\
\text { (Landing) }\end{array}$ & & 0.085 & 0.047 & & 0.085 & 0.008 \\
\hline
\end{tabular}

\footnotetext{
${ }^{6}$ Computed as impact weight multiplied by within-impact weight
} 


\begin{tabular}{|c|c|c|c|c|c|c|c|}
\hline & $\begin{array}{l}\text { 90-SEL noise } \\
\text { contour area } \\
\text { (Landing) }\end{array}$ & & 0.159 & 0.089 & & 0.159 & 0.014 \\
\hline & $\begin{array}{l}\text { 100-SEL noise } \\
\text { contour area } \\
\text { (Landing) }\end{array}$ & & 0.256 & 0.143 & & 0.256 & 0.023 \\
\hline Climate & LTO total fuel & 0.220 & 1 & 0.220 & 0.720 & 1 & 0.720 \\
\hline \multirow{3}{*}{$\begin{array}{l}\text { Air } \\
\text { quality }\end{array}$} & LTO total HC & \multirow[t]{3}{*}{0.220} & 0.4 & 0.088 & \multirow[t]{3}{*}{0.190} & 0.4 & 0.076 \\
\hline & LTO total CO & & 0.2 & 0.044 & & 0.2 & 0.038 \\
\hline & LTO total $\mathrm{NO}_{\mathrm{x}}$ & & 0.4 & 0.088 & & 0.4 & 0.076 \\
\hline
\end{tabular}

Fig. 4 shows the values of the EIAm for each aircraft category, and for the impacts at a local (left) and global (right) scale (on the basis of the weighting factors $\left(w_{i}\right)$ shown in Table 7). Comparing the local and global scenarios, the average value of EIAm remains similar for the category $4($ EIAm $=0.44)$; and a slight decrease in the average EIAm is observed for the categories 1 and 2 at the global scale (EIAm $=0.07$ and 0.17 respectively) as compared to the local scale (EIAm $=0.08$ and 0.22 respectively). For the specific case of the category 3, an important increase in the average EIAm is observed at the global scale (EIAm $=0.81$ ) as compared to the local scale $($ EIAm $=0.70)$. 

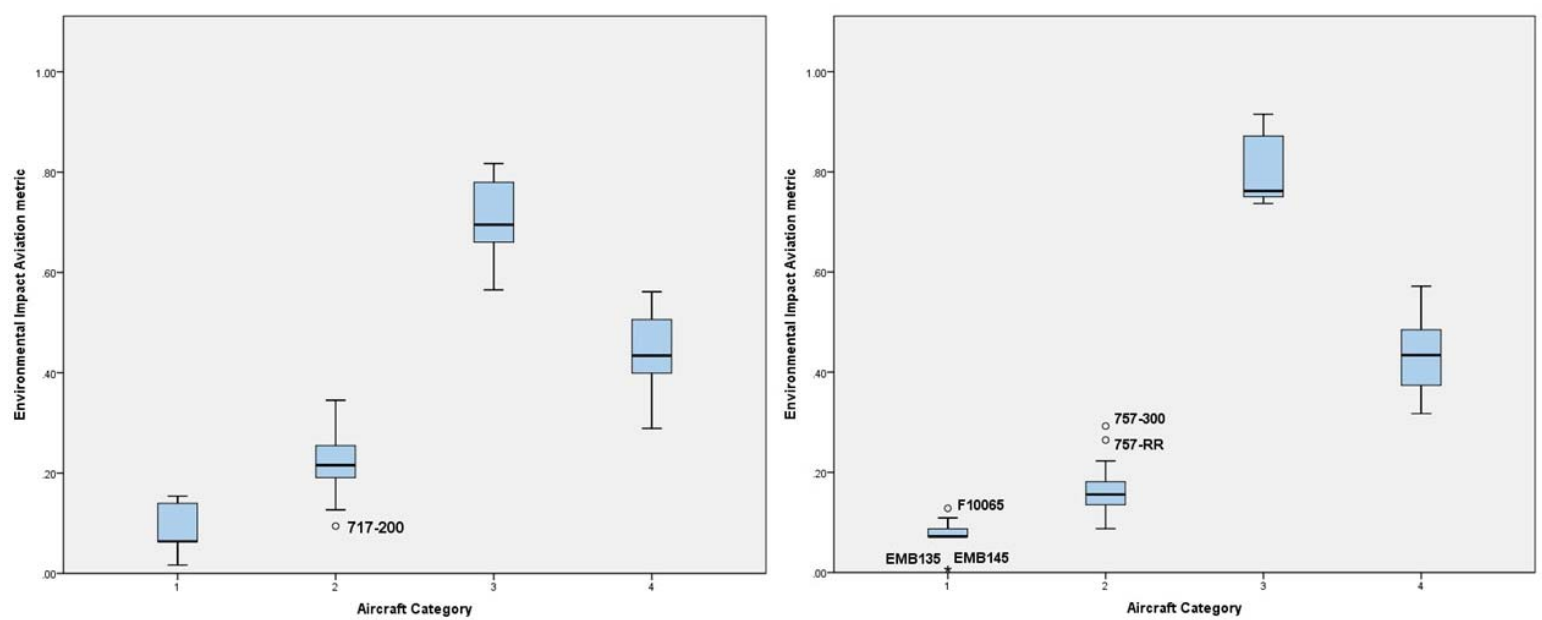

Fig. 4. Box-plot diagram with the value of the environmental impact aviation metric (EIAm) for each aircraft category, with weighting factors $\left(w_{i}\right)$ for the assessment of local (left) and global (right) impacts.

\subsection{Airport noise calculation with representative-in-class aircraft}

For the computation of airport noise outputs a hypothetical airport was created. As shown in Fig. 5, three flight paths for departure operations were simulated: (Dep-1) easterly straight-out flight track, (Dep-2) easterly flight track with a 180 degrees turning angle at 7.5 $\mathrm{km}$ from the start-of-roll (SOR) point, and (Dep-3) westerly straight-out flight track. Also, two flight paths for arrival operations were simulated (Fig. 4): (App-1) westerly straight-in flight track, and (App-2) easterly flight track with a 60 degrees turning angle at $15 \mathrm{~km}$ from the touchdown point. For this hypothetical airport, the noise contours (and noise contour areas) of 54, 57 and $60 \mathrm{~dB}(\mathrm{~A}) \mathrm{L}_{\mathrm{Aeq}, 16 \mathrm{~h}}$ were computed for two aircraft fleets: Heathrow airport (daytime ${ }^{7}$ ) fleet (Lee et al., 2017a) and Gatwick airport (daytime) fleet (Lee et al. 2017b) in the year 2015. Table 8 shows the distribution of flights across the selected aircraft categories for each airport. The 54, 57 and $60 \mathrm{~dB}(\mathrm{~A}) \mathrm{L}_{\text {Aeq, } 16 \mathrm{~h}}$ noise contours were selected because of their use for assessing the percentage of annoyed/highly annoyed in the vicinity of airports in the UK (CAA, 2017).

\footnotetext{
${ }^{7}$ From 07:00 to $23: 00$
} 


\section{Table 8}

Distribution of daytime flights across the selected aircraft categories for Heathrow airport fleet in 2015 and Gatwick airport fleet in 2015. In brackets it is shown the percentage relative to the overall number of movements at the airport. *Note that business jets and aircraft with less than 0.1 movements/day were not considered.

\begin{tabular}{|c|c|c|c|c|c|c|c|}
\hline $\begin{array}{l}\text { Aircraft } \\
\text { category }\end{array}$ & $\begin{array}{l}\text { Representative-in- } \\
\text { class aircraft }\end{array}$ & $\begin{array}{l}\text { Dep- } \\
1\end{array}$ & $\begin{array}{l}\text { Dep- } \\
2\end{array}$ & $\begin{array}{l}\text { Dep- } \\
3\end{array}$ & $\begin{array}{l}\text { App- } \\
1\end{array}$ & $\begin{array}{l}\text { App- } \\
2\end{array}$ & Total \\
\hline \multicolumn{8}{|c|}{ Heathrow airport (year 2015) } \\
\hline 1 & CRJ-900 & 3.3 & 2.1 & 2.9 & 3.3 & 5.0 & $\begin{array}{l}16.5 \\
(1.3 \%)\end{array}$ \\
\hline 2 & A321-232 & 164.0 & 102.5 & 143.5 & 164.0 & 246.1 & $\begin{array}{l}820.2 \\
(64.5 \%)\end{array}$ \\
\hline 3 & $747-8$ & 22.8 & 14.2 & 19.9 & 22.8 & 34.2 & $\begin{array}{l}113.9(9.0 \\
\%)\end{array}$ \\
\hline 4 & A330-343 & 64.3 & 40.2 & 56.3 & 64.3 & 96.5 & $\begin{array}{l}321.7 \\
(25.3 \%)\end{array}$ \\
\hline \multicolumn{8}{|c|}{ Gatwick airport (year 2015) } \\
\hline 1 & CRJ-900 & 4.0 & 2.5 & 3.5 & 4.0 & 6.1 & $\begin{array}{l}20.2 \\
(2.7 \%)\end{array}$ \\
\hline 2 & A321-232 & 132.6 & 82.9 & 116.0 & 132.6 & 198.9 & $\begin{array}{l}663.0 \\
(89.5 \%)\end{array}$ \\
\hline 3 & $747-8$ & 2.5 & 1.6 & 2.2 & 2.5 & 3.8 & $\begin{array}{l}12.6 \\
(1.7 \%)\end{array}$ \\
\hline 4 & A330-343 & 9.0 & 5.6 & 7.8 & 9.0 & 13.4 & $\begin{array}{l}44.8 \\
(6.0 \%)\end{array}$ \\
\hline
\end{tabular}




\section{Table 9}

Computational time (in seconds) comparison between the whole fleet, the four representative-in-class aircraft and the most utilized aircraft conditions for two cases: Heathrow airport fleet in 2015 and Gatwick airport fleet in 2015. In brackets it is shown the computational time reduction (\%) relative to the whole fleet.

\begin{tabular}{|l|l|l|}
\hline & Heathrow fleet 2015 & Gatwick fleet 2015 \\
\hline Whole fleet (s) & 670.7 & 672.8 \\
\hline Representative-in-class aircraft (s) & $163.9(76 \%)$ & $146.9(78 \%)$ \\
\hline Most utilized aircraft (s) & $88.3(87 \%)$ & $94.3(86 \%)$ \\
\hline
\end{tabular}

To validate the simplification of reducing the whole aircraft fleet to the four representative-in-class aircraft (see Section 3.1) for computing airport noise outputs, the noise contours (and noise contour areas) described above were calculated with INM for two conditions: (i) with the whole aircraft fleet and (daytime) movements as presented in Lee et al. $(2017 \mathrm{a}, \mathrm{b})^{8}$, (ii) from the aircraft fleet data presented in Lee et al. $(2017 \mathrm{a}, \mathrm{b})^{8}$, the number of aircraft (daytime) movements were summed within each corresponding category, and then assigned to the representative-in-class aircraft (see Table 8). Moreover, the changes in computational time ${ }^{9}$ and model accuracy when the aircraft fleet is reduced to four representative-in-class aircraft were compared to the changes in computational time and accuracy with only the most utilized aircraft, A320-232 (Heathrow airport in 2015) and A319131 (Gatwick airport in 2015). The noise computations in INM were carried out with a fixed spacing of $200 \mathrm{~m}$, with a total number of grid points of 112,800 .

\footnotetext{
${ }^{8}$ Excluding business jets and aircraft with less than 0.1 movements/day.

${ }^{9}$ Defined in this research as the time used by INM for computing noise outputs.
} 


\section{Table 10}

Noise contour areas $\left(\mathrm{km}^{2}\right)$ computed for the conditions: (i) whole aircraft fleet, (ii) only 4 representative-in-class aircraft and (iii) only the most utilized aircraft, using Heathrow airport fleet in 2015 and Gatwick airport fleet in 2015. In brackets it is shown the absolute percentage error.

\begin{tabular}{|l|l|l|l|l|l|l|}
\hline \multirow{2}{*}{$\begin{array}{l}\mathrm{L}_{\text {Aeq, } 16 \mathrm{~h}} \\
\text { contour }\end{array}$} & \multicolumn{4}{|l|}{ Heathrow fleet 2015 } & \multicolumn{2}{|l|}{ Gatwick fleet 2015 } \\
\cline { 2 - 7 } & $\begin{array}{l}\text { Whole } \\
\text { fleet }\end{array}$ & $\begin{array}{l}\text { 4 representative- } \\
\text { in-class aircraft }\end{array}$ & $\begin{array}{l}\text { Most } \\
\text { utilized } \\
\text { aircraft }\end{array}$ & $\begin{array}{l}\text { Whole } \\
\text { fleet }\end{array}$ & $\begin{array}{l}\text { 4 representative- } \\
\text { in-class aircraft }\end{array}$ & $\begin{array}{l}\text { Most } \\
\text { utilized } \\
\text { aircraft }\end{array}$ \\
\hline $54 \mathrm{dBA}$ & 105.3 & $107.8(2 \%)$ & $\begin{array}{l}66.5(- \\
38 \%)\end{array}$ & 60.4 & $58.0(-4 \%)$ & $\begin{array}{l}40.4(- \\
30 \%)\end{array}$ \\
\hline $57 \mathrm{dBA}$ & 66.3 & $67.6(2 \%)$ & $\begin{array}{l}41.7(- \\
38 \%)\end{array}$ & 35.6 & $35.9(1 \%)$ & $\begin{array}{l}23.3(- \\
35 \%)\end{array}$ \\
\hline $60 \mathrm{dBA}$ & 40.2 & $41.4(3 \%)$ & $\begin{array}{l}24.4(- \\
41 \%)\end{array}$ & 20.5 & $21.6(5 \%)$ & $\begin{array}{l}13.5(- \\
38 \%)\end{array}$ \\
\hline
\end{tabular}

The reduction of the whole aircraft fleet to only the four representative-in-class aircraft identified in Section 3.1 allows a significant decrease in computational time when calculating noise contours. As shown in Table 9, the reduction in computational time ranges between $76 \%$ (with Heathrow aircraft fleet in 2015) and 78\% (with Gatwick aircraft fleet in 2015). However, this substantial increase in the computational efficiency is not at the expense of an equally substantial decrease in accuracy. With the four representative-in-class aircraft found (Table 4), the noise contour areas for the 54,57 and $60 \mathrm{~dB}(\mathrm{~A}) \mathrm{L}_{\mathrm{Aeq}, 16 \mathrm{~h}}$ were calculated with relatively minor uncertainty (within a range of $-4 \%$ to $+5 \%$ ) as compared with the calculations using the whole aircraft fleet (Table 10). As observed in Table 10, similar results were obtained for two completely different aircraft fleet: Gatwick airport (year 2015) had a very unbalanced distribution of aircraft movements with $90 \%$ corresponding to category 2 , and only $3 \%, 2 \%$ and $6 \%$ corresponding to categories 1, 3 and 4 respectively (see Table 8) Heathrow airport (year 2015) had a more balanced distribution of aircraft movements with $65 \%$ corresponding to category $2,25 \%$ to category $4,9 \%$ to category 3 , and only $1 \%$ to category 1 (see Table 8 ). On the other hand, with only the most utilized aircraft the computational time was reduced in 
$87 \%$ and $86 \%$ (Heathrow and Gatwick airports respectively), but also the model accuracy dropped dramatically as shown in Table 10 .
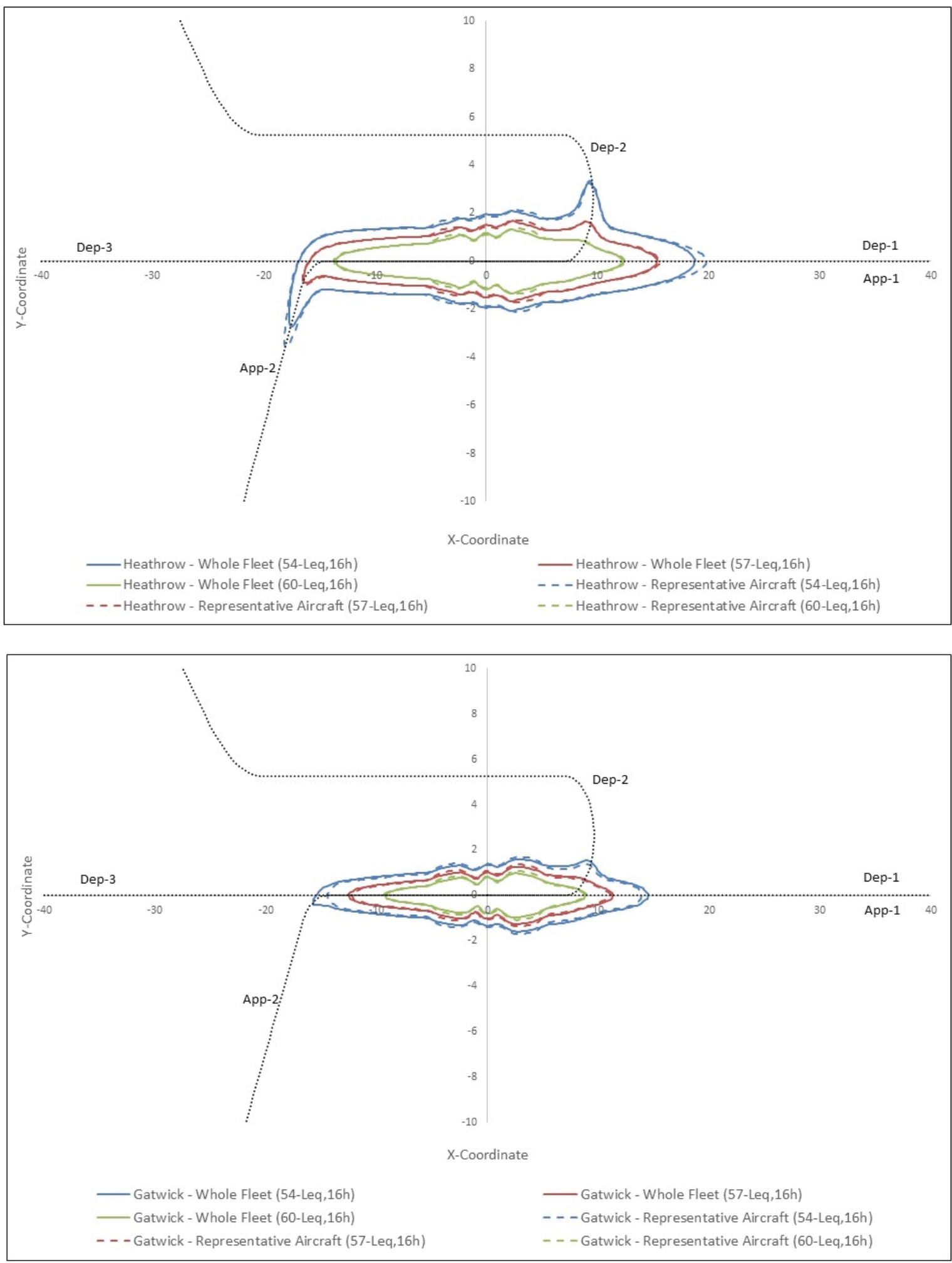

Fig. 5. Noise contours computed for two conditions: (i) whole aircraft fleet and (ii) only 4 
representative-in-class aircraft, using Heathrow airport fleet in 2015 (top) and Gatwick airport fleet in 2015 (bottom).

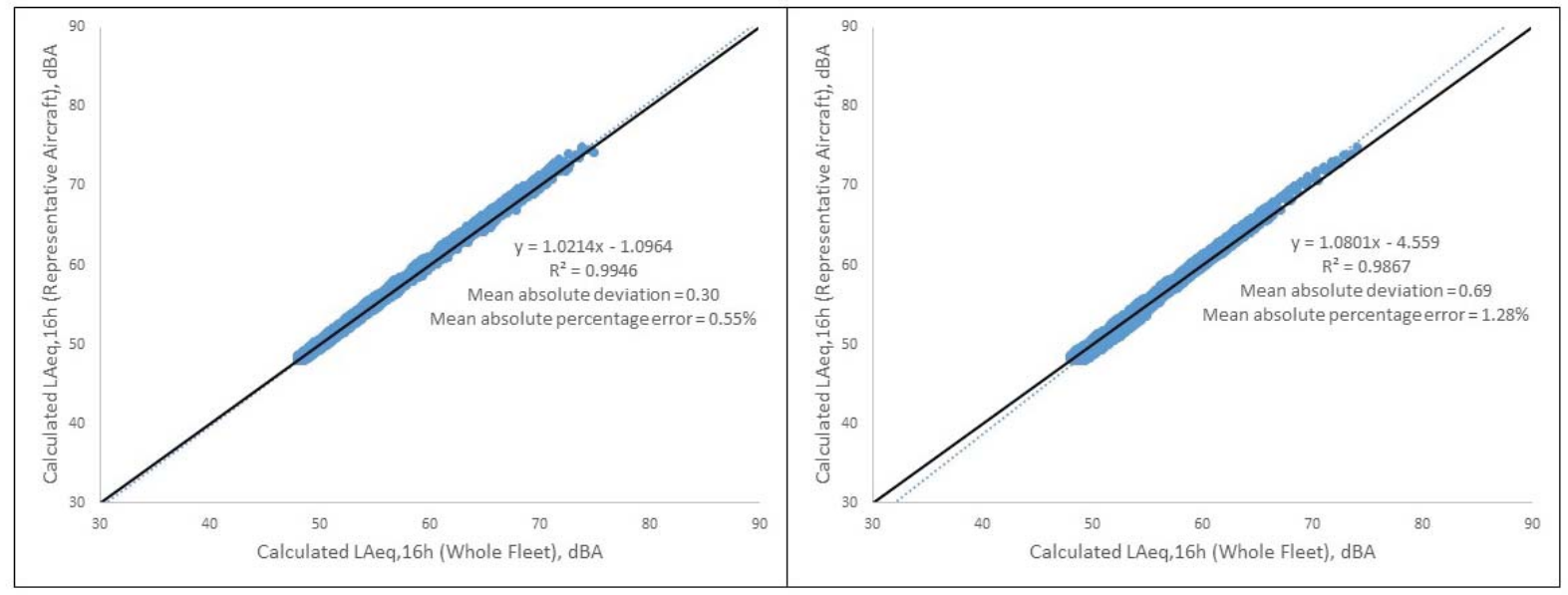

Fig. 6. Scatter diagram between $L_{\text {Aeq, } 16 h}$ calculated with (i) the whole aircraft fleet and with (i) the 4 representative-in-class aircraft, using Heathrow airport fleet in 2015 (left) and Gatwick airport fleet in 2015 (right).

From a fleet-level perspective the four representative-in-class aircraft identified were able to capture the noise characteristics of the aircraft fleet as shown in Fig. 5. The calculations with the four representative-in-class aircraft accurately replicated the spatial distribution of the sound-levels obtained with the whole fleet (Fig. 5). Moreover, Fig. 6 displays the $\mathrm{L}_{\mathrm{Aeq}, 16 \mathrm{~h}}$ at each grid point, as calculated with INM using the whole aircraft fleet and using only the 4 representative-in-class aircraft. Within the range $48-75 \mathrm{~dB}(\mathrm{~A})$, the mean absolute deviation and the mean absolute percentage error with the representative aircraft simplification was 0.30 $\mathrm{dB}$ and $0.55 \%$ respectively (Heathrow fleet 2015), and $0.69 \mathrm{~dB}$ and $1.28 \%$ respectively (Gatwick fleet 2015).

\section{Discussion}


The computational time of airport noise models, either high-fidelity models such as INM or simplified models (e.g. Bernardo et al., 2015; Torija et al., 2017), is highly sensitive to the number of aircraft types in the flight schedule. This research reduces the aircraft fleet in the UK by defining four representative-in-class aircraft, based on a statistical process (see Section 3.1). This classification and selection of representative-in-class aircraft lessens the combinatorial nature of the fleet, and therefore maximizes the computational efficiency of airport noise models (Bernardo et al., 2015). As described in Section 3.3, and for the specific cases tested in the paper, the simplification of using four representative-in-class aircraft allows a reduction of about $80 \%$ of the computational time without decreasing the accuracy when calculating airport noise outputs (within a range of $-4 \%$ to $+5 \%$ ). LeVine et al. (2017) found that the representative vehicles approach demonstrated more robustness than the average generic vehicles approach for the computation of noise outputs in the set of 94 US airports evaluated. LeVine et al. (2017) suggested that this finding was due to the better performance of the representative vehicles approach in airports with a low volume of operations, and where the operations were dominated by only one aircraft type; and also they stated that the average generic vehicles approach outperformed the representative vehicles approach for airports with more operations spread across a variety of aircraft. In this research the representative-in-class approach for computing airport noise outputs was validated using the aircraft fleets (in year 2015) of the two main airports in the UK: Heathrow and Gatwick airports. Heathrow airport had a higher volume of operations, with operations more evenly distributed across the four aircraft categories identified, while Gatwick airport had a lower volume of operations, with most operations concentrated in the aircraft category 2. As shown in Table 10 and Figs. 5 and 6, the representative-in-class approach achieved similar high accuracy values in both airports evaluated. 
The aircraft classification performed in this research was based on variables for the physical characterization of the aircraft, and variables describing the aircraft noise and engine exhaust emissions at a vehicle-level. As demonstrated in Section 3.3, the aircraft representing the 4 aircraft categories identified were able to accurately represent the fleet in terms of distribution of sound-levels around airports. Similarly, these representative-in-class aircraft can be used for approximating the climate and air quality impact of aviation at a fleet-level. Enabling a large number of scenarios to be computed in a short period of time, this statistically based classification and selection of representative-in-class vehicles can therefore be especially useful for multi-objective optimization analysis of aircraft technologies for minimizing environmental impact (Afonso et al., 2017; Jimenez and Mavris, 2017), aircraft route optimization for minimizing aircraft noise and emissions ( $\mathrm{Li}$ et al., 2015), and economicenvironmental tradeoffs analysis (Rosskopf et al., 2014).

As mentioned above, the aircraft database used in this research included out-ofproduction aircraft. Out-of-production aircraft were included because they were considered absolutely necessary for the environmental modeling of the aircraft fleet currently in use in the UK. During the design of the aircraft database it was anticipated that the inclusion of out-ofproduction aircraft might have some effect in the selection of the most appropriate baseline cases for aircraft technology evaluation. However, as demonstrated with Fig. 7, the inclusion of the out-of-production aircraft has not had any effect on the selection of the representativein-class aircraft (from an environmental perspective). Fig. 7 shows that within each category the corresponding representative-in-class aircraft selected is the aircraft with the smallest distance to EIAm centroid, regardless the inclusion or exclusion of the out-of-production vehicles. 

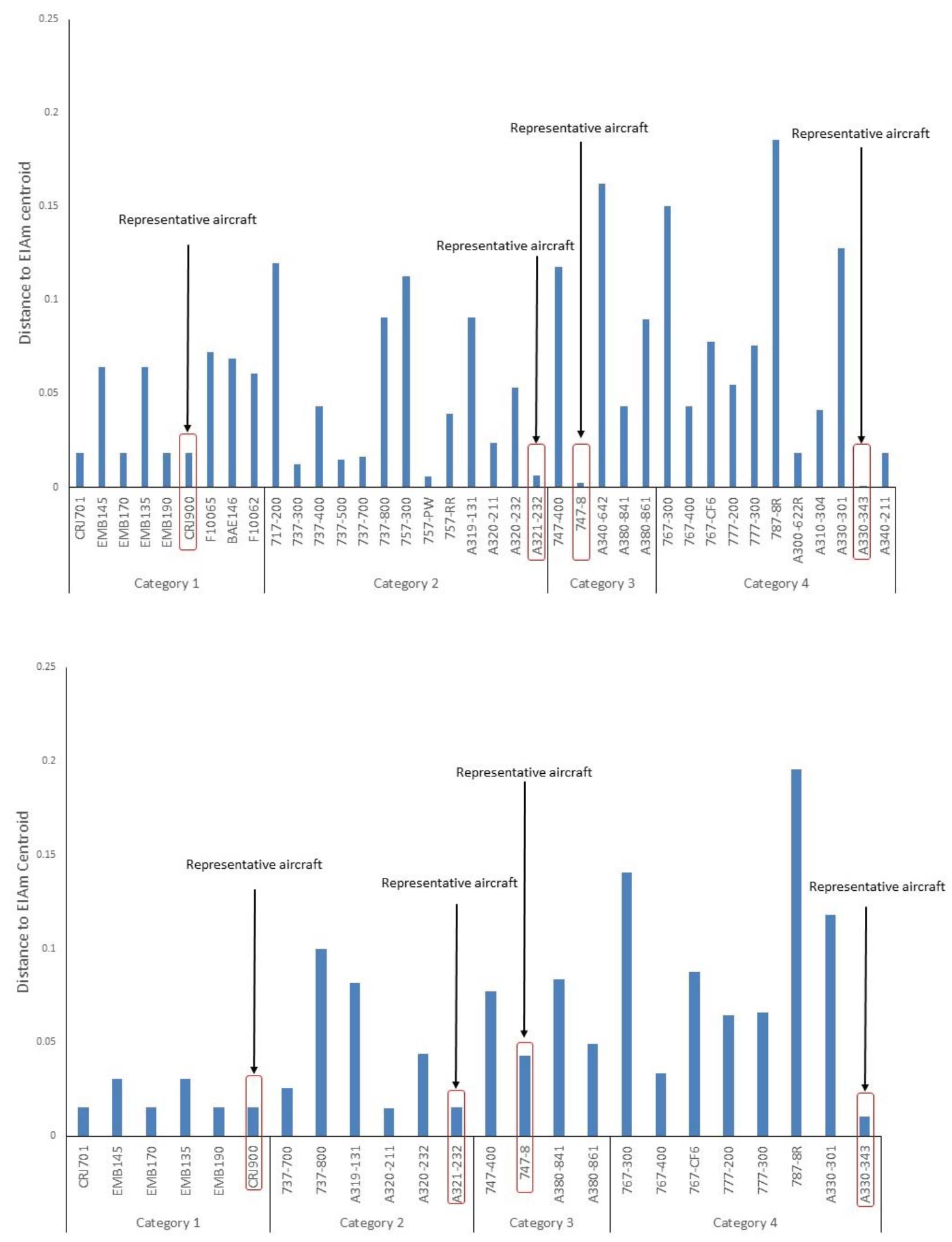

Fig. 7. Distance to EIAm centroid within each category, for all the aircraft in the database (top) and only in-production aircraft (bottom).

This paper defines a metric for the assessment of the aircraft environmental impact (see EIAm in Section 3.2). Although it is defined for individual aircraft, this metric could be 
extended to assess the cumulative environmental impact of aviation scenarios. As illustrated in Section 3.2.1, the aviation stakeholders or expert panels can apply different weighting factors to the set of environmental variables composing the EIAm depending on the priorities or particular circumstances of specific cases, e.g. for assessing environmental impacts at a local or on a global scale. EIAm can therefore be useful for the integrated assessment of the environmental benefit/drawbacks of policies, technologies, and operational procedures within the framework of aviation decision-making (Mahashabde, et al., 2011). EIAm can also be used by airlines for the assessment process of strategies to increase their environmental performance (Miyoshi and Merkert, 2015).

Defined on the basis of aircraft noise and engine exhaust emissions, the four representative-in-class aircraft can be used as baseline cases for examining the potential environmental benefits of novel technological capabilities (Adib et al., 2014) in a lower fidelity state, but also for projecting environmental emissions and noise for future aviation scenarios with varying air traffic demands and fleet renewal (SA, 2012, 2013). The representative-inclass approach, as presented in this paper, is of direct application for assessing the evolution of technology improvements within conventional tube and wing aircraft, or for the analysis of aircraft retirements where those aircraft are replaced with newer technology but would be within the same category. However, if on the basis of both physical characteristics and environmental performance, novel (radical) aircraft concepts cannot be assigned to any of the aircraft categories identified, then the categories and representative-in-class aircraft will need to be updated. Once the appropriate baseline cases are defined, then the fleet-level environmental benefits of technological changes within the design space (of each baseline case) can be examined. For the specific case of aircraft noise, the framework developed by Synodinos et al. (2017) can be used for generating noise-power-distance (NPD) data for novel aircraft designs, which then can be used by airport noise models (e.g. Torija et al., 2017)) for 
investigating the potential benefit of such designs for reducing the impact of aviation noise around airports. The framework developed by Synodinos et al. (2017) combines noise prediction methods for individual aircraft noise sources with aircraft noise and performance data to estimate noise variations with respect to a baseline case, where noise levels are known.

\section{Conclusions}

This paper presented the results of a statistically based classification of the UK commercial aircraft fleet into four representative aircraft categories on the basis of aircraft physical characteristics and aircraft noise and engine exhaust emissions metrics. The four aircraft categories found correspond to 2 engine regional aircraft, 2 engine short-medium haul aircraft, 2 engine long haul aircraft, and 4 engine long haul aircraft. These aircraft categories and the aircraft selected as representative-in-class are consistent with the selection of reference aircraft for aircraft technology studies conducted by the ICAO CAEP. The total fuel during the LTO cycle, the departure and landing weight, the total $\mathrm{NO}_{\mathrm{x}}$ emitted during the LTO cycle and the 90-SEL noise contour area during landing conditions were the variables with the highest contribution to the discrimination between the four aircraft categories. The four aircraft categories were well differentiated in terms of their environmental impact (EIAm), but only the environmental impact of regional and short/medium haul aircraft (categories 1 and 2), and long haul aircraft (categories 3 and 4) was found statistically different.

Reducing the combinatorial nature of the fleet, i.e. assigning the scheduled movements of the whole fleet to the corresponding four representative-in-class aircraft selected in this paper, allows a reduction of approximately $80 \%$ of the computational time. This significant increase of the computational efficiency is achieved with a relatively minor decrease in accuracy (between $-4 \%$ and $+5 \%$ as compared to the results with the whole fleet). Although 
based on a classification and selection at a vehicle-level, the four representative-in-class aircraft were able to accurately approximate the distribution of the fleet sound-levels in the specific airport scenarios tested.

The simplification of the whole aircraft fleet to four aircraft appropriately representing the fleet noise and environmental emissions (i.e. climate and air quality) characteristics has two important benefits: (i) maximization of computational efficiency, enabling a rapid computation of a large number of fleet-level analysis for the optimization of aircraft technologies and flight routes to minimize environmental impact, and for economic-environmental tradeoffs; (ii) availability of representative baseline aircraft for the high-level examination of the environmental benefits (at a fleet-level) of aircraft technological developments.

\section{Acknowledgements}


This work was partly supported by the Engineering and Physical Science Research Council (grant number EP/M026868/1), and by Innovate UK (Grant No. TSB/113086). The authors would also like to thank the anonymous reviewers for their valuable comments and suggestions to improve the quality of the paper.

Appendix A. Supplementary data 
Supplementary data related to this article can be found at [link provided by Journal of Air Transport Management].

\section{References}


Adib, M., Catalano, F., Hileman, J., Huff, D., Ito, T., Joselzon, A., Khaletskiy, Y., Michel, U., Mongeau, L., Tester, B. J. 2014. Novel aircraft noise technology review and medium and long term noise reduction goals," ICAO Doc 10017 Report, Montreal, Canada.

Aeronautics Science and Technology Subcommittee (ASTS), 2010. National aeronautics research and development plan (biennial update), Technical report, Washington, D.C., USA.

Afonso, F., Vale, J., Lau, F., Suleman, A., 2017. Performance based multidisciplinary design optimization of morphing aircraft. Aerosp. Sci. Technol. 67, 1-12.

Airbus, 2016. Global market forecast: Mapping demand 2016/2035, Technical report, Blagnac, France.

Ashok, A., Lee, I.H., Arunachalam, S., Waitz, I.A., Yim, S.H., Barrett, S.R., 2013. Development of a response surface model of aviation's air quality impacts in the United States. Atmos. Environ. 77, 445-452.

Barrett, S.R.H., Britter, R.E., Waitz, I.A., 2013. Impact of aircraft plume dynamics on airport local air quality. Atmos. Environ. 74, 247-258.

Bernardo, J., Boling, B., Bonnefoy, P.A., Burdette, G., Hansman, R.J., Kirby, M., Lim, D., Mavris, D., Mozdzanowska, A., Nam, T., Pfaender, H., Waitz, I.A., Yutko, B., 2012. $\mathrm{CO}_{2}$ emission metrics for commercial aircraft certification: A national airspace system perspective. A PARTNER Project 30 Findings Report, Report NO. PARTNER-COE2012-002, Cambridge, USA.

Bernardo, J.E., Kirby, M., Mavris, D., 2015. Development of a rapid fleet-level noise computation model. J. Aircraft 52, 721-733. 
Bernardo, J.E., Kirby, M., Mavris, D., 2016. Probabilistic assessment of fleet-level noise impacts of projected technology improvements. J. Air Transp. Manag. 57, $26-42$.

Boeing, 2016. Current market outlook 2016-2035, Technical report, Seattle, USA.

Civil Aviation Authority (CAA), 2017. Survey of noise attitudes 2014: Aircraft. Technical report CAP 1506, London, UK.

Clean Sky Joint Undertaking, 2012. Clean Sky at a glance: Bringing sustainable air transport closer, Technical report, Brussels, Belgium.

De Amorim, R.C., 2015. Feature relevance in Ward's hierarchical clustering using the $\mathrm{L}_{\mathrm{p}}$ norm. J. Classif. 32 (1), 46-62.

Del Rosario, R., 2014. The NASA Fixed Wing Project: Green Technologies for Future Aircraft Generations, Fedden Lecture. Cranfield University, Cranfield, United Kingdom.

Department for Transport (DfT), 2013. UK aviation forecast, Technical report, London, UK.

Dikshit, P.N., Crossley, W.A., 2009. Airport noise model suitable for fleet-level studies. Proceedings of the $9^{\text {th }}$ AIAA Aviation Technology, Integration, and Operations Conference (ATIO), South Carolina, USA.

Durmaz, V., 2011. Organizational change for the environmentally sustainable airport management. EMAJ Emerg. Mark. J. 1 (2), 13-20.

EMPA, 2010. FLULA2, Ein Verfahren zur Berechnung und Darstellung der Fluglärmbelastung. Technische Programm-Dokumentation (FLULA2, a method for the calculation and illustration of aircraft noise exposure. Technical program documentation). Version 4. Dübendorf, Switzerland: Empa, Swiss Federal Laboratories for Materials Science and Technology, Laboratory for Acoustics/Noise Control. 
European Commission (EC), 2011. Flightpath 2050: Europe's vision for aviation, Technical report, Luxembourg.

Federal Aviation Administration (FAA), 2008. Integrated Noise Model (INM) Version 7.0 Technical Manual, Rept. FAA-AEE-08-01, Washington, D.C.

Federal Aviation Administration (FAA), 2012. Portfolio of goals, FY 2011 methodology report, FAA flight plan performance measures, Technical report, Washington, D.C., USA.

Federal Aviation Administration (FAA), 2014. Continuous lower emissions, energy, and noise (CLEEN) program, Technical report, Washington, D.C., USA.

Fidell S, Silvati L., 2004. Parsimonious alternative to regression analysis for characterizing prevalence rates of aircraft noise annoyance. Noise Control Eng. 52, $56-68$.

Hollingsworth, P., Sulitzer, D., 2011. Investigating the potential of using Quota count as a design metric. J. Aircraft 38 (6), 1894-1902.

ICAO Annex 16, 2008. International standards and recommended practices, Environmental protection. Volume II “Aircraft engine emissions”, $3^{\text {rd }}$ ed., Montreal, Canada.

Jimenez, H., Mavris, D., 2017. Pareto-optimal aircraft technology study for environmental benefits with multi-objective optimization. J. Aircraft 54(5), 1860-1876.

Jones, K., and Cadoux, R., 2009. Metrics for aircraft noise, ERCD Report 0904, London, UK.

Lee, J., Cebrian, G., Edmonds, L., Patel, J., Rhodes, D., 2017a. Noise exposure contours for Heathrow airport 2015. Technical report, ERCD 1601, London, UK. 
Lee, J., Cebrian, G., Edmonds, L., Patel, J., Rhodes, D., 2017b. Noise exposure contours for Gatwick airport 2015. Technical report, ERCD 1602, London, UK.

LeVine, M.J., Bernardo, J.E., Kirby, M., Mavris, D.N., 2017. Average generic vehicle method for fleet-level analysis of noise and emission tradeoffs. J Aircraft (in Press), https://doi.org/10.2514/1.C034368

Li, J., Chen, N., Ng, H.K., Sridhar, B., 2015. Simple tool for aircraft noise-reduction route design. Proceedings of the $15^{\text {th }}$ AIAA Aviation Technology, Integration, and Operations Conference (ATIO), Dallas, USA.

Mahashabde, A., Wolfe, P., Ashok, A., Dorbian, C., He, Q., Fan, A., Lukachko, S., Mozdzanowska, A., Wollersheim, C., Barrett, S.R.H., Locke, M., Waitz, I.A., 2011. Prog. Aerosp. Sci. 47, 15-52.

Masiol, M., Harrison, R.M., 2014. Aircraft engine exhaust emissions and other airport-related contributions to ambient air pollution: A review. Atmos. Environ. 95, 409-455.

Miedema, H.M., 2007. Annoyance caused by environmental noise: elements for evidencebased noise policies. J. Soc. Issues 63 (1), 41-57.

Miyoshi, C., Merkert, R., 2015. The economic and $\mathrm{CO}_{2}$ emissions performance in aviation: an empirical analysis of major European airlines. In: Fahimnia, B., Bell, M., Hensher, D., Sarkis, J. (eds) Green Logistics and Transportation. Greening of Industry Networks Studies, vol. 4. Springer, Cham.

Ollerhead, B.J., Rhodes, D.P., Viinikainen, M.S., Monkman, D.J., Woodley, A.C., 1999. The UK Civil Aircraft Noise Contour Model ANCON: Improvements in Version 2, Environmental Research and Consultancy Dept., U.K. Civil Aviation Authority, Rept. 9842, London. 
Ramanathan, V., Feng, Y., 2009. Air pollution, greenhouse gases and climate change: global and regional perspectives. Atmos. Environ. 43, 37-50.

Rosskopf, M., Lehner, S., Gollnick, V., 2014. Economic-environmental trade-offs in long-term airline fleet planning. J. Air Transp. Manag. 34, 109-115.

Schäffer, B., Plüss, S., Thomann, G., 2014. Estimating the model-specific uncertainty of aircraft noise calculations. App Acoust. 84, 58-72.

Sustainable Aviation (SA), 2012. $\mathrm{CO}_{2}$ road-map. Technical report, London, UK.

Sustainable Aviation (SA), 2013. The SA noise road-map: A blueprint for managing noise from aviation sources to 2050. Technical report, London, UK.

Synodinos, A.P., Self, R.H., Torija, A.J., 2017. Framework for predicting noise-powerdistance curves for novel aircraft designs. J Aircraft (in Press), https://doi.org/10.2514/1.C034466

Tetzloff, I.J., Crossley, W.A., 2014. Measuring systemwide impacts of new aircraft on the environment. J. Aircraft 51, 1483-1489.

Torija, A.J., Ruiz, D.P., Ramos-Ridao, A.F., 2013. Application of a methodology for categorizing and differentiating urban soundscapes using acoustical descriptors and semantic-differential attributes. J. Acoust. Soc. Am. 134 (1), 791-802.

Torija, A.J., Ruiz, D.P., 2016. Automated classification of urban locations for environmental noise impact assessment on the basis of road-traffic content. Expert Syst. Appl. 53, 113.

Torija, A.J., Self, R.H., Flindell, I.H., 2017. A model for the rapid assessment of the impact of aviation noise near airports. J. Acoust. Soc. Am. 141, 981-995. 
Torija, A.J., Self, R.H., Flindell, I.H., 2018. Airport noise modelling for strategic environmental impact assessment of aviation. Appl Acoust. 132, 49-57.

Wolfe, P.J., Yim, S.H.L., Lee, G., Ashok, A., Barrett, S.R.H., Waitz, I.A., 2014. Near-airport distribution of the environmental costs of aviation. Transp Policy 34, 102-108.

Wolfe, P.J., Kramer, H.L., Barrett, S.R.H., 2017. Current and future noise impacts of the UK hub airport. J. Air Transp. Manag. 58, 91-99.

Yim, S.H.L., Stettler, M.E.J., Barrett, S.R.H., 2013. Air quality and public health impacts of UK airports. Part II: impacts and policy assessment. Atmos. Environ. 67, 184-192. 